\title{
NEAREST GREEDY ALGORITHM FOR SOLVING A SINGLE LANDFILL SITE SELECTION WITH RESOURCE REQUIREMENTS
}

\author{
NUR AZRIATI MAT*, AIDA MAUZIAH BENJAMIN AND SYARIZA ABDUL-RAHMAN \\ Institute of Strategic Industrial Decision Modelling, School of Quantitative Sciences, Universiti Utara Malaysia, Kedah, \\ Malaysia.
}

*Corresponding author: nur_azriati@ahsgs.uum.edu.my

Submitted final draft: 26 November 2019 Accepted: 7 February 2020

http://doi.org/10.46754/jssm.2020.07.011

\begin{abstract}
Landfill site selection has appeared to be an important waste management issue for future landfill planning. The selection of suitable landfill sites involves several alternative sites, along with evaluation criteria. Previously, most studies solved the landfill site selection problem by using the geographic information systems (GIS) and the multiple criteria decision making (MCDM) methods. GIS is used to identify suitable sites for a new landfill, while MCDM is used to rank the candidate sites based on the score calculated for each site. With that this paper presents a new approach that ranks the related candidate sites. These candidate sites were ranked based on several vital resource requirements, such as total travel distance to transport collected waste to the landfill, number of vehicles/ drivers required for the collection and total working hours of drivers affect the operating cost of the selected landfill. To be precise, all requirements as described above have been provided when a particular site is selected as the new landfill. These resources are identified by using the heuristic technique, namely nearest greedy. This approach was further tested on a benchmark problem set, namely waste collection vehicle routing problem with time windows. The results serve to aid the waste management team to select the most suitable location for landfill siting, besides listing the influential resource requirements for landfill site selection planning in selecting a new landfill site.
\end{abstract}

Keywords: Landfill site selection, landfill siting, waste collection benchmark, heuristic, resources.

\section{Introduction}

Rapid population growth, urbanisation development, and fast economic growth have been determined as the common factors that have contributed to the increasing amount of waste generation rates in many nations worldwide. Thus, it is necessary to generate a more effective and efficient method or model to address solid waste management problem. Moreover, a number of approaches are available to manage and dispose solid waste, such as composting (Jara-Samaniego et al., 2017), incineration (Yang et al., 2017), and landfilling (Vosoogh et al., 2017). Regardless of the varied methods available to dispose solid waste, landfilling is still the preferred choice due to its simplicity and low costing, especially in developing countries (Rahmat et al., 2017).

In general, a good landfill site selection plan should be beneficial to both the government and the community in terms of long-term survival and free from pollutions. Hence, the initial step in the preparation of the plan is determining the most suitable location to establish waste disposal facilities that would not negatively affect the aspects of economy, ecology, and environmental health (Chang et al., 2008). In selecting a new landfill site, all important criteria, including environmental, economic, and social elements, must be considered in the preliminary screening and landfill suitability assessment phase. Nevertheless, the criteria used may differ between research as they rely on the type of landfill (municipal or hazardous), as well as physical and ecological conditions of the research areas (Moghaddas \& Namaghi, 2011; Bahrani et al., 2016). In fact, a comprehensive study carried out by Mat et al. (2016) reported the varied landfill selection criteria across many nations. 
Although prior studies have employed various criteria related to environmental, economic, and social aspects, these studies have failed to investigate the best utilisation of their limited resources in locating a new landfill site, which may cause a problem in the implementation phase. In addition, resource requirements need to be finalised early within a project lifecycle as these demands often surpass initial estimates and incapability's to secure resource commitments, which possess the potential to dampen project efforts (Reel \& Systems, 1999; Somers \& Nelson, 2001). Furthermore, in landfill selection, resource requirements (e.g. vehicles, drivers, and fuel) that aid the transportation of solid waste from customers to landfill facilities must be defined at the beginning stage and allocated equally to the most suitable landfill facilities. With that, customers can be served efficiently during waste collection. This should enhance the present solid waste management system to be more effective.

On top of that, determination of resource requirements is indeed necessary when planning for landfill selection with limited resources. In such situations, trade of decision must be made regarding which landfill site should be open to receive the available resource. For instance, for the farthest landfill site, more maintenance cost should be allocated due to the long distance covered by the particular vehicle in collecting waste from customers until disposal at the landfill site. Other resources that can be considered are the transportation cost, number of vehicles and drivers as well as drivers' working hours. Therefore, we believe that these resources affect the operating costs of a landfill.

In this paper, a real life waste collection vehicle routing problem with time windows (VRPTW) benchmark problem has been used to test the proposed algorithm. The benchmark problem is based on the solid waste management services in North America, of which nearly 26000 collections are conducted to collect about 80 million tons of garbage a year (Sahoo et al., 2005).

Since there are many criteria that belong to environmental, economic and social groups that must be weighed in during landfill site selection process, this problem has often been viewed as a multi-criteria decision-making problem (MCDM) (Onut \& Soner, 2008). As such, most past research solved landfill site selection problems by using statistical procedures, geographic information systems (GIS), MCDM methods, and fuzzy techniques. For example, Anderson \& and Greenberg (1982) applied the matrix statistical approach to evaluate land use suitability to locate new hazardous landfill facilities based on water supply, physical, and cultural criteria. Meanwhile, Al-Bakri et al. (1988) identified and evaluated a potential landfill site in Shuiba Industrial Area located at Kuwait by using a weighting/scaling scoring system. Nonetheless, the initial combination of GIS and analytical hierarchy process (AHP) was proposed by Siddiqui et al. (1996) for landfill selection in Cleveland County found at Oklahoma. Charnpratheep et al. (1997) combined the fuzzy set theory (FST) and AHP into a raster-based GIS for preliminary screening of landfill sites in Thailand. Cheng et al. (2002) applied the MCDM approach (simple weighted addition (SWA), weighted product (WP) method, TOPSIS, cooperative game theory (CGT), and ELECTRE) to solve issues related to landfill selection in Regina of Saskatchewan Canada.

Additionally, in 2003, similar MCDM approaches were utilised by combining them with inexact mixed integer linear programming (IMILP) methods to detect an optimal landfill site selection and a waste-flow-allocation pattern in Regina (Cheng et al., 2003). On top of that, Şener et al. (2006) identified an appropriate landfill in the vicinity of Ankara by using the integration of GIS, simple additive weighting (SAW), and AHP, whereas Gemitzi et al. (2007) integrated GIS, fuzzy logic, AHP, and order weighted average (OWA) for municipal landfill selection in Greece. Besides that, Chang et al. (2008) combined GIS with fuzzy MCDM for landfill siting in Texas, while Aragonés-Beltrán et al. (2010) used the Analytic Network Process (ANP) to identify the best location for landfill siting in Spain. On the other hand, Gorsevski 
et al. (2012) evaluated landfill suitability in Macedonia by using GIS-based fuzzy MCDM approach, while Arkoc (2014) solved MSW landfill selection at Çorlu District by employing GIS with an overlay analysis. Furthermore, Torabi-Kaveh et al. (2016) coupled GIS analysis with a fuzzy AHP to locate a suitable landfill site in Iranshahr County located in Iran. Additionally, more information concerning decision-making techniques in solving landfill site selection problems can be referred to the article published by Mat et al. (2017). Table 1 presents a summary of recent studies concerning landfill site selection problems.

With that, this paper presents a landfill site selection problem that emerges when a set of candidate landfill sites are already available and further evaluation is required to select the best site among them. In such a case, it is common for local authorities to opt for the most economical landfill in terms of operational cost incurred at the time of waste collection from customers until disposal of at the landfill site. Sahoo et al. (2005) reported that onethird of waste management revenue is derived from landfill disposal and the remaining waste collection services. Moreover, given that the vast majority of income comes from waste collection services, increment in management level and technical efficiency (routing, dispatching, and maintenance) should be given priority. Hence, the utilisation of available resources can reduce operating costs (Sahoo et al., 2005). Besides, identifying the most suitable location for landfill facilities could also reduce operational cost, as well as routes taken by waste collection vehicles and the number of vehicles needed (Benjamin \& Beasley, 2013).

Table 1: Recent works on landfill site selection problem

\begin{tabular}{ll}
\hline \multicolumn{1}{c}{ Author(s) } & \multicolumn{1}{c}{ Descriptions } \\
\hline Vosoogh et al. (2017) & $\begin{array}{l}\text { Zoning the pollution potential of the Mashhad aquifer by } \\
\text { using modified DRASTIC method and GIS to assess both old and new } \\
\text { landfill sites. }\end{array}$ \\
\hline Rahmat et al. (2017) & $\begin{array}{l}\text { Determined a suitable site to dispose solid waste in Behbahan city in Iran } \\
\text { by using a combination of GIS and } \\
\text { AHP. }\end{array}$ \\
\hline Jamshidi-Zanjani \& Rezaei & $\begin{array}{l}\text { Selected a landfill site in Markazi province in at Iran by using different } \\
\text { methods, including ANP combined with fuzzy linguistic quantifier, ordered } \\
\text { weighted average (OWA), and weighted linear combination (WLC) } \\
\text { approaches in GIS. }\end{array}$ \\
\hline Chabuk et al. (2017) & $\begin{array}{l}\text { Detected the most suitable landfill site by using GIS and } \\
\text { two varied methods of MCDM }\end{array}$ \\
\hline Al-Ruzouq et al. (2018) & $\begin{array}{l}\text { A combination of fuzzy membership and AHP in GIS } \\
\text { environment was used for landfill siting in Sharjah city, } \\
\text { United Arab Emirates. }\end{array}$ \\
\hline Ding et al. (2018) & $\begin{array}{l}\text { A selection of Construction and Demolition } \\
\text { (C\&D) waste landfill sites in Shenzhen, China using GIS } \\
\text { and AHP methods presented }\end{array}$ \\
\hline Kahraman et al. (2018) & $\begin{array}{l}\text { Information axiom into a trapezoidal intuitionistic fuzzy set to overcome } \\
\text { doubts among experts in deciding the best location for landfill siting in } \\
\text { Istanbul included }\end{array}$ \\
\hline
\end{tabular}


Thus, in this study, in order to determine resource requirements for selecting good landfill site, the problem is solved as waste collection VRPTW. In constructing vehicle routes, various solution techniques have been successfully applied by previous research, for instances, heuristic approaches (i.e. Molina et al., 2019), exact methods (i.e. Lysgaard et al., 2004), and technology applications (i.e. Chaudhary et al., 2019). Of all these, heuristic technique is the most appropriate technique for finding solutions involving real-world applications (Louati \& Chabchoub, 2019). The greedy algorithm is one of the heuristics approaches which is often used (Karabulut \& Tasgetiren, 2014; DelgadoAntequera et al., 2019) in generating initial solution. Therefore, in this study, the nearest greedy (NG) algorithm is used for analysing resources such as total travel distance to transport collected waste to the landfill, number of drivers required for the collection and total working hours of drivers. All these resources affect waste management operating cost. With that, in this paper, a single landfill site selection problem by using NG algorithm had been investigated to reduce the operating costs incurred during the waste collection process.

\section{Materials and Methods}

This section presents the real-life waste collection VRPTW benchmark problem sets and new approach to rank the candidate landfill sites used in this paper.

\section{Benchmark dataset}

This paper investigated the waste collection vehicle routing problem with time windows (VRPTW) benchmark problem employed to test the proposed landfill site selection model with resource requirements embedded into the model. The benchmark problem was introduced by Kim et al. (2006). The problem consisted of varying numbers of customers, landfill sites, vehicle capacity, and route capacity per day. The characteristics of each dataset are displayed in Table 2.

The first column of Table 2 lists the name of all datasets to represent the total number of nodes (i.e. depot, customers, and landfill site) involved in each dataset. Figure 1 depicts an example of dataset 102 (i.e. a total of 102 nodes) which comprised of 99 customers, 2 landfill sites, and 1 depot. In this study, the following scenario is illustrated where the waste collection process starts with an empty vehicle from the depot, collecting waste from one location (termed as customer) and unloaded the accumulated waste at the landfill. Then, the vehicle will leave the landfill and collect more waste from other customers' locations until no waste is found to be collected and then return to the depot with an empty capacity. The number

Table 2: Characteristics of Waste Collection VRPTW benchmark problem

\begin{tabular}{cccc}
\hline $\begin{array}{c}\text { Dataset / number } \\
\text { of nodes }\end{array}$ & $\begin{array}{c}\text { Number of } \\
\text { customers }\end{array}$ & $\begin{array}{c}\text { Number of landfills } \\
\text { sites }\end{array}$ & $\begin{array}{c}\text { Vehicle capacity } \\
\text { (cubic yards) }\end{array}$ \\
\hline 102 & 99 & 2 & 280 \\
335 & 330 & 4 & 243 \\
804 & 784 & 19 & 280 \\
1051 & 1048 & 2 & 200 \\
1351 & 1347 & 3 & 255 \\
1599 & 1596 & 3 & 280 \\
1932 & 1927 & 4 & 462 \\
2100 & 2092 & 7 & 462 \\
\hline
\end{tabular}


of landfill sites displayed in the third column of Table 2 is considered as the potential candidate landfill sites. For instance, dataset 102 consists of 2 potential landfill sites and the vehicle capacity is limited to 280 yards. Besides, for all datasets, the maximum number of customers served by each vehicle is 500 on a daily basis. Meanwhile, the duration of lunch break for drivers is an hour. Other than that, the vehicle travels in static speed, which is 40 miles per hour (mph). Furthermore, the coordinate of each node (depot/customers/landfill sites) provided in the dataset is in feet.

\section{The New Approach}

The new approach proposed in this paper is projected to solve single landfill site selection problem, as illustrated in Figure 2. In this research, the ranking process starts by generating the distance and travel time matrix $\left(\begin{array}{lll}n & \times & n\end{array}\right)$ for each dataset, where $\mathrm{n}$ is the total number of nodes (depot/landfill site/customer). The number of matrices constructed depends on the number of landfill site. For example, dataset 102 has two candidate landfill sites. Thus, the nearest greedy (NG) technique adopted from (Mat et al., 2017; Mat et al., 2018) was executed twice with varied distance and travel time at each execution. In the first run, distance and travel time between the nodes were used based on the coordinate of candidate landfill 1 . Next, in the second run, distance and travel time between the nodes had been based on the coordinate of candidate landfill 2. The total distance travelled, and the numbers of constructed routes were then calculated for each solution. After that, the solutions obtained were sorted in ascending order based on the total distance travelled. Lastly, the rank of the solutions is displayed, where the lowest distance is regarded as the best solution.

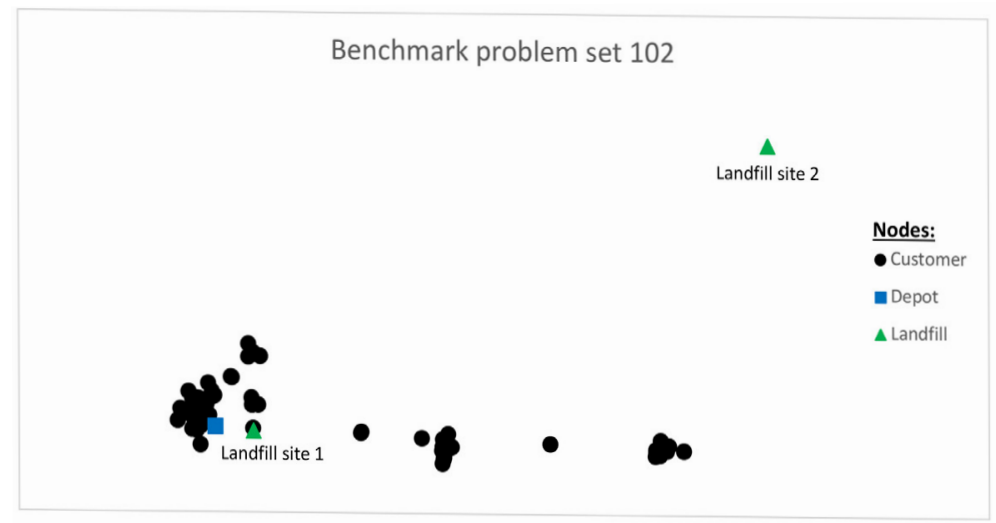

Figure 1: Location of nodes for dataset 102

Calculate the total number of nodes, $n$.
Create a 2-dimensional distance matrix of $n \times n$.
Create a 2-dimensional travel time matrix of $n \times n$.
FOR $i=1$ : number of candidate landfill sites
Construct vehicle routes using nearest greedy technique
Calculate total distance travelled
Calculate number of constructed routes
Save solution $i$
END FOR
FOR $i=1$ : number of solutions
Sort solution $i$ into ascending order based on the total distance travelled
END FOR
Display rank of the solutions

Figure 2: Pseudo-code of ranking process 
Basically, the NG technique selected the closest customer from the present node to be served based on a set of problem constraints, as listed in the following:

- Maximum number of customers served per day

- Route capacity per day

- Driver's rest break

- Vehicle travel speed

- Time windows (depot/customer/landfill site)

- Service time

- Each customer is serviced exactly once

- Each vehicle route starts and ends at the depot

- The amount of waste collected at each customer cannot exceed vehicle capacity

- The vehicle must be emptied at the landfill site before continuing servicing the customer or before returning to the depot (final trip)

Further elaboration pertaining to the technique employed by $\mathrm{NG}$ in constructing a vehicle route is illustrated in Figure 3. In addition, this study presents a new set of initial solutions constructed for each vehicle route that must start from the depot. A new vehicle route was constructed by identifying the nearest distance from a set of customers that needs to be scheduled from depot 0 . Once $i i$ was confirmed, the variables, the total capacity, and the present vehicle capacity were updated. Next, the rest period allocated to the drivers was determined. The drivers were permitted to take a break during their break time. Otherwise, the driver would need to identify the next closest customer $j j$ to be serviced from customer $i i$. At the same time, the variables were updated.

Next, the vehicle was checked if it was loaded with waste. If the vehicle was full of load, a candidate landfill site was suggested for disposal of waste. Upon waste disposal, the candidate landfill site was included in the present vehicle route, in which the variables, the total capacity, and the present vehicle capacity were updated.

After that, the system determined if there was remaining customer(s) that required waste disposal service. Upon opening the time window, the vehicle would have to service the customers. In the absence of customers and after emptying the vehicle, the vehicle would need to return to the depot. Thus, the variables: total vehicle capacity and total customer visited per day, would be updated. However, a new vehicle would be used to collect waste from any remaining customer(s), indicating increment in the number of drivers. The new vehicle would eventually undergo the whole process starting from the initial phase. The whole process would be terminated as soon as all customers have sought the service.

Furthermore, it is worthy to highlight that the whole process was executed $n$ times based on the number of candidate landfill sites derived from the dataset. For example, dataset 102 has two possible landfill sites. Thus, it was executed twice to construct two solutions for the dataset. In the first run, all collected waste from the customers was unloaded at landfill site 1, while in the second run; all the waste was unloaded at landfill site 2 .

Both solutions (obtained from both runs) provided resource requirements to serve all customers in terms of the total distance travelled and the number of drivers needed. The resource requirements from both solutions were further compared so as to choose the best landfill site for the dataset. The comparisons are discussed in detail in the next subsection.

\section{Results and Discussion}

This paper applied resource requirements to select the best landfill site. The outcome of the total distance travelled and the number of drivers needed had been determined for the waste collection process. As such, the NG technique was coded in $\mathrm{C}++$ and run on a Pentium ${ }^{\circledR}$ DualCore CPU T4300@2.10GHz with 3.00 GB memory. Besides, this very approach was tested 


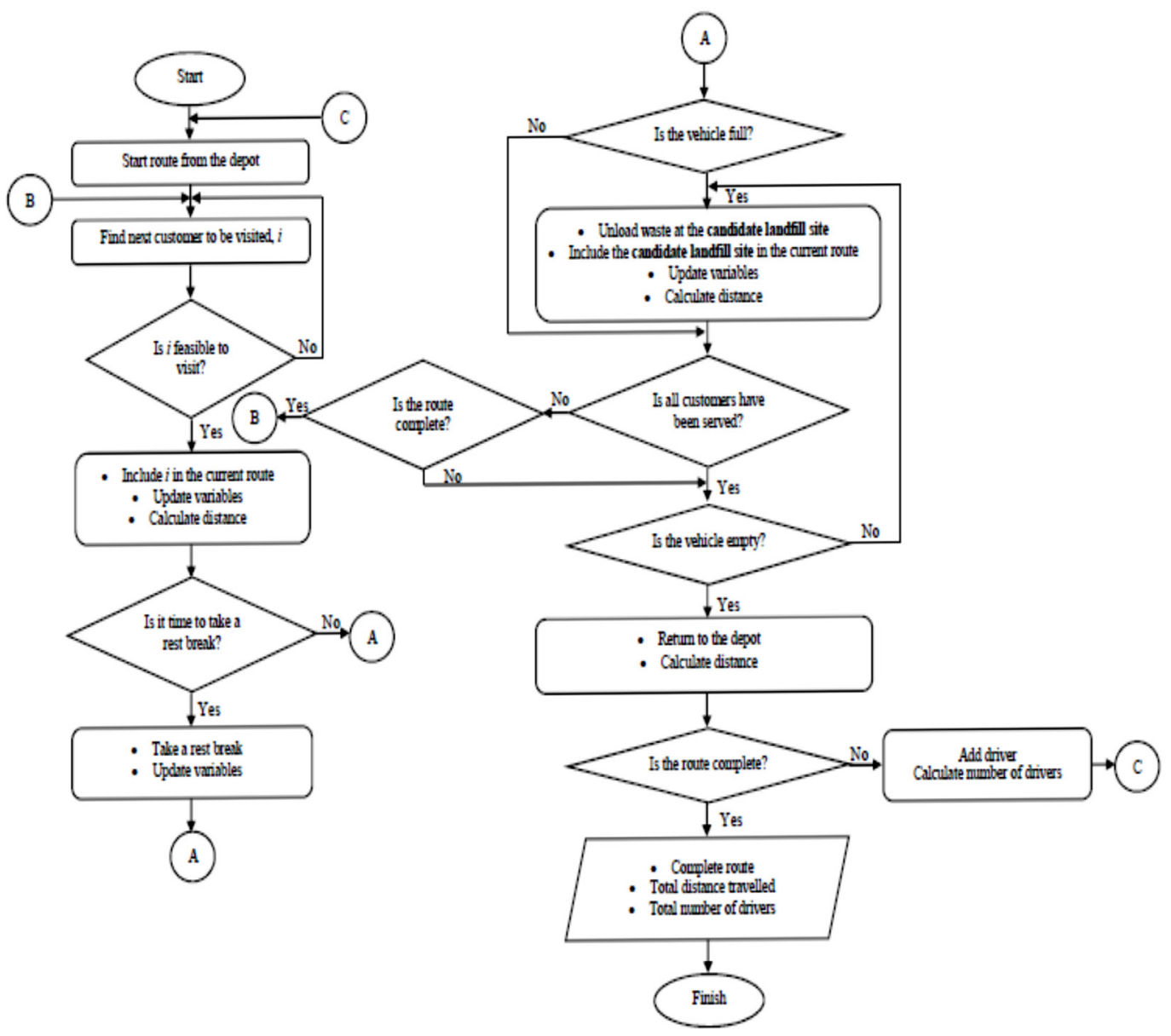

Figure 3: Flow chart of the NG technique to construct vehicle routes

on the same benchmark problem employed by Kim et al. (2006) and Benjamin and Beasley (2010, 2013). With that, Table 3 until Table 10 present the resource requirements needed to serve all customers if each candidate site was selected as a landfill site. The third and the fourth columns of the tables display the resource requirements, whereas the last column shows the ranking of the candidate landfill sites.
Table 3 presents the resource requirements that served 99 customers based on two different landfill candidate sites. Based on the solution proposed by NG technique, if site 1 was selected, the waste management team would need to hire three drivers to serve the customers and the total distance travelled by all the drivers would have been 257.21 miles. Meanwhile, if site 2 was selected, they also need to hire the same number

Table 3: Computational results for dataset 102

\begin{tabular}{cccccc}
\hline Dataset & Landfill ID & $\begin{array}{c}\text { Total distance } \\
\text { (miles) }\end{array}$ & $\begin{array}{c}\text { Number of } \\
\text { drivers }\end{array}$ & $\begin{array}{c}\text { Average } \\
\text { working } \\
\text { hour per } \\
\text { driver }\end{array}$ & $\begin{array}{c}\text { Ranking } \\
\text { based on total } \\
\text { distance }\end{array}$ \\
\hline 102 & $\mathbf{1}$ & $\mathbf{2 5 7 . 2 1}$ & $\mathbf{3}$ & $\mathbf{4}$ & $\mathbf{1}$ \\
& 2 & 701.66 & 3 & 8 & 2 \\
\hline
\end{tabular}


of drivers, but the total distance would have been higher when compared to site 1 (an increment by $172.8 \%$ ). Average working hour per driver if site 1 was selected is 4 hours. While, average working hour for site 2 is 8 hours, this is due to the location of landfill site 2 which is far from the customers (refer to Figure 1). Moreover, as observed, the waste management team was given two options, either site 1 or site 2 . If site 1 was selected, they could save thrice the resources required (i.e., fuel consumption), as compared to site 2, where the distance travelled by all drivers was longer.
Table 4 presents the resource requirements needed to serve 330 customers based on four different landfill candidate sites. Based on the solution proposed by NG technique, site 1 emerged as the best choice, when compared to the rest. The total distance travelled by all drivers was 213.28 miles and average working hour per driver if site 1 were selected is 5 hours. Meanwhile, all candidate landfill sites would require six drivers, the same number.

Table 5 presents that dataset 804 proposed two candidate sites: sites 3 and 9. Both sites would require similar number of resources $(6$

Table 4: Computational results for dataset 335

\begin{tabular}{cccccc}
\hline Dataset & Landfill ID & $\begin{array}{c}\text { Total } \\
\text { distance } \\
\text { (miles) }\end{array}$ & $\begin{array}{c}\text { Number of } \\
\text { drivers }\end{array}$ & $\begin{array}{c}\text { Average } \\
\text { working } \\
\text { hour per } \\
\text { driver }\end{array}$ & $\begin{array}{c}\text { Ranking } \\
\text { based on total } \\
\text { distance }\end{array}$ \\
\hline \multirow{3}{*}{335} & $\mathbf{1}$ & $\mathbf{2 1 3 . 2 8}$ & $\mathbf{6}$ & $\mathbf{5}$ & $\mathbf{1}$ \\
& 2 & 552.35 & 6 & 6 & 2 \\
& 3 & 688.37 & 6 & 7 & 3 \\
\hline
\end{tabular}

Table 5: Computational results for dataset $804 \mathrm{x}$

\begin{tabular}{|c|c|c|c|c|c|}
\hline Dataset & Landfill ID & $\begin{array}{l}\text { Total distance } \\
\text { (miles) }\end{array}$ & $\begin{array}{l}\text { Number of } \\
\text { drivers }\end{array}$ & $\begin{array}{c}\text { Average } \\
\text { working } \\
\text { hour per } \\
\text { driver }\end{array}$ & $\begin{array}{c}\text { Ranking } \\
\text { based on total } \\
\text { distance }\end{array}$ \\
\hline \multirow{19}{*}{804} & 1 & 1545.27 & 7 & 9 & 4 \\
\hline & 2 & 2582.25 & 10 & 9 & 14 \\
\hline & 3 & 801.05 & 6 & 8 & 1 \\
\hline & 4 & 1781.39 & 8 & 9 & 6 \\
\hline & 5 & 1987.39 & 8 & 9 & 9 \\
\hline & 6 & 2037.66 & 8 & 10 & 11 \\
\hline & 7 & 2582.25 & 10 & 9 & 14 \\
\hline & 8 & 805.48 & 5 & 10 & 2 \\
\hline & 9 & 801.05 & 6 & 8 & 1 \\
\hline & 10 & 1495.67 & 7 & 9 & 3 \\
\hline & 11 & 1754.50 & 8 & 9 & 5 \\
\hline & 12 & 1818.47 & 8 & 9 & 7 \\
\hline & 13 & 3670.64 & 11 & 10 & 14 \\
\hline & 14 & 2448.19 & 10 & 9 & 13 \\
\hline & 15 & 2007.04 & 8 & 10 & 10 \\
\hline & 16 & 2074.75 & 8 & 9 & 12 \\
\hline & 17 & 1781.39 & 8 & 9 & 6 \\
\hline & 18 & 1866.26 & 8 & 9 & 8 \\
\hline & 19 & 1545.27 & 7 & 9 & 4 \\
\hline
\end{tabular}


drivers, 8 hours working duration per driver in average and a total of 801.05 miles in travel distance). Therefore, the authorities are given two options to choose either site 3 or site 9 as a landfill site. If the authorities faced limited resources, such as drivers, they could choose site 8 , which would need only five drivers to serve 784 customers. However, the total travel distance of all drivers was 805. 48 miles, indicating an increment by 4.43 miles $(0.55 \%)$, when compared to sites 3 and 9.

Table 6 presents the resource requirements that would be required to serve 1048 customers based on two candidate sites. Based on the solution proposed by $\mathrm{NG}$ technique, both sites would need eighteen drivers to serve the customers, while the lowest total distance travelled by all drivers would have been 3048.53 miles (site 1). If site 2 were selected, the same number of drivers would be required, but the total distance would escalate, as compared to site 1 (an increment by $1.73 \%$ ). Average working hour per driver would be 7 hours.

The results depicted in Table 7 shows the resource requirements needed to serve 1347 customers based on three different landfill candidate sites. Based on the solution proposed by NG technique, site 3 appeared to be the most suitable site that gave the lowest total travel distance in serving all the customers. The average working hour per driver for site 3 would be 7 hours. However, all the candidate sites would require the same number of drivers, a total of 8 .

Table 8 displays the resource requirements needed to serve 1596 customers based on two different candidate landfill sites. Based on the

Table 6: Computational results for dataset $1051 \mathrm{X}$

\begin{tabular}{cccccc}
\hline Dataset & Landfill ID & $\begin{array}{c}\text { Total } \\
\text { distance } \\
\text { (miles) }\end{array}$ & $\begin{array}{c}\text { Number of } \\
\text { drivers }\end{array}$ & $\begin{array}{c}\text { Average } \\
\text { working } \\
\text { hour per } \\
\text { driver }\end{array}$ & $\begin{array}{c}\text { Ranking } \\
\text { based on total } \\
\text { distance }\end{array}$ \\
\hline \multirow{2}{*}{1051} & $\mathbf{1}$ & $\mathbf{3 0 4 8 . 5 3}$ & $\mathbf{1 8}$ & $\mathbf{7}$ & $\mathbf{1}$ \\
& 2 & 3101.20 & 18 & 8 & 2 \\
\hline
\end{tabular}

Table 7: Computational results for dataset 1351

\begin{tabular}{cccccc}
\hline Dataset & Landfill ID & $\begin{array}{c}\text { Total distance } \\
\text { (miles) }\end{array}$ & $\begin{array}{c}\text { Number of } \\
\text { drivers }\end{array}$ & $\begin{array}{c}\text { Average } \\
\text { working } \\
\text { hour per } \\
\text { driver }\end{array}$ & $\begin{array}{c}\text { Ranking } \\
\text { based on } \\
\text { total distance }\end{array}$ \\
\hline \multirow{2}{*}{1351} & 1 & 1290.81 & 8 & 8 & 2 \\
& 2 & 1382.95 & 8 & 8 & 3 \\
\hline
\end{tabular}

Table 8: Computational results for dataset 1599

\begin{tabular}{cccccc}
\hline Dataset & Landfill ID & $\begin{array}{c}\text { Total distance } \\
\text { (miles) }\end{array}$ & $\begin{array}{c}\text { Number of } \\
\text { drivers }\end{array}$ & $\begin{array}{c}\text { Average } \\
\text { working } \\
\text { hour per } \\
\text { driver }\end{array}$ & $\begin{array}{c}\text { Ranking } \\
\text { based on } \\
\text { total distance }\end{array}$ \\
\hline \multirow{2}{*}{1599} & 1 & 3012.37 & 18 & 9 & 2 \\
& $\mathbf{2}$ & $\mathbf{1 8 4 7 . 1 9}$ & $\mathbf{1 5}$ & $\mathbf{1 0}$ & $\mathbf{1}$ \\
\hline
\end{tabular}


solution proposed by NG technique, if site 2 were selected, the waste management team would need to hire fifteen drivers to serve the customers and the total distance travelled by all drivers would have been 1847.19 miles. Average working hour per driver would be 10 hours for site 2 . On the other hand, if site 1 were selected, more drivers and more coverage of distance (an increase of $63.08 \%$ ) would be needed, when compared to site 2 .

The computational results presented in Table 9 show the resource requirements needed to serve 1927 customers based on four different candidate landfill sites. Based on the solution proposed, site 4 provided the lowest distance in serving all the customers. However, the same number of drivers (sixteen) would serve all the customers for each candidate landfill site and the average working hour for each of driver is similar for all sites which is 13 hours.
Lastly, Table 10 demonstrates the resource requirements needed to serve 2092 customers based on seven different candidate landfill sites. Based on the solution proposed by NG technique, site 3 offered a better solution, as compared to the rest. If site 3 were selected, the waste management team would need to hire eighteen drivers to serve all the customers, the total distance travelled of all drivers would have been 2300.23 miles and 10 hours would be the average working hour of all drivers.

\section{Conclusion}

This paper has introduced a new approach to rank the candidate landfill sites based on resource requirements, such as the total distance travelled and the number of drivers needed. As such, the nearest greedy $(\mathrm{NG})$ technique was used to evaluate both resources. The proposed approach

Table 9: Computational results for dataset 1932

\begin{tabular}{|c|c|c|c|c|c|}
\hline Dataset & Landfill ID & $\begin{array}{c}\text { Total } \\
\text { distance } \\
\text { (miles) }\end{array}$ & $\begin{array}{c}\text { Number of } \\
\text { drivers }\end{array}$ & $\begin{array}{c}\text { Average } \\
\text { working } \\
\text { hour per } \\
\text { driver }\end{array}$ & $\begin{array}{c}\text { Ranking } \\
\text { based on } \\
\text { total distance }\end{array}$ \\
\hline \multirow{4}{*}{1932} & 1 & 1431.17 & 16 & 13 & 3 \\
\hline & 2 & 1384.60 & 16 & 13 & 2 \\
\hline & 3 & 1431.89 & 16 & 13 & 4 \\
\hline & 4 & 1368.36 & 16 & 13 & 1 \\
\hline
\end{tabular}

Table 10: Computational results for dataset 2100

\begin{tabular}{cccccc}
\hline Dataset & Landfill ID & $\begin{array}{c}\text { Total } \\
\text { distance } \\
\text { (miles) }\end{array}$ & $\begin{array}{c}\text { Number of } \\
\text { drivers }\end{array}$ & $\begin{array}{c}\text { Average } \\
\text { working } \\
\text { hour per } \\
\text { driver }\end{array}$ & $\begin{array}{c}\text { Ranking } \\
\text { based on } \\
\text { total distance }\end{array}$ \\
\hline \multirow{2}{*}{2100} & 1 & 3258.36 & 20 & 10 & 4 \\
& $\mathbf{3}$ & 5203.36 & 25 & 9 & 7 \\
& 4 & $\mathbf{2 3 0 0 . 2 3}$ & $\mathbf{1 8}$ & $\mathbf{1 0}$ & $\mathbf{1}$ \\
& 5 & 3687.20 & 21 & 10 & 6 \\
& 6 & 3502.47 & 21 & 10 & 5 \\
& 2949.76 & 19 & 10 & 2 \\
\hline
\end{tabular}


was tested on a waste collection vehicle routing problem with time windows (VRPTW) dataset suggested by Kim et al. (2006). As a result, the computational findings showed that both resources (travel distance and drivers) greatly influenced the landfill site selection problem. If the number of customers who seek the service is higher, then more resources would need to be allocated. In the near future, the authors would like to consider a multiple landfill site selection in the attempt to devise more reliable solutions.

\section{Acknowledgements}

The authors would like to extend their gratitude to Universiti Utara Malaysia and the Malaysian Ministry of Higher Education for providing the research funding under the Fundamental Research Grant Scheme (Code: 13225) to carry out this research work. The authors would also like to thank the reviewers for the encouraging and fruitful comments to improve the quality of this paper.

\section{References}

Al-Bakri, D., Shublaq, W., Kittaneh, W., \& AlSheikh, Z. (1988). Site selection of a waste disposal facility in Kuwait, Arabian Gulf. Waste Management \& Research, 6(4), 363377.

Al-Ruzouq, R., Shanableh, A., Omar, M., \& Al-Khayyat, G. (2018). Macro and micro geo-spatial environment consideration for landfill site selection in Sharjah, United Arab Emirates. Environmental Monitoring and Assessment, 190(3), 147.

Anderson, R. F., \& Greenberg, M. R. (1982). Hazardous waste facility siting a role for Planners. Journal of the American Planning Association, 48(2), 204-218.

Aragonés-Beltrán, P., Pastor-Ferrando, J. P., García-García, F., \& Pascual-Agulló, A. (2010). An Analytic network process approach for siting a municipal solid waste plant in the metropolitan area of
Valencia (Spain). Journal of Environmental Management, 91(5), 1071-1086.

Arkoc, O. (2014). Municipal solid waste landfill site selection using geographical information systems: A case study from Çorlu, Turkey. Arabian Journal of Geosciences, 7(11), 4975-4985.

Bahrani, S., Ebadi, T., Ehsani, H., Yousefi, H., \& Maknoon, R. (2016). Modeling landfill site selection by multi-criteria decision making and fuzzy functions in GIS, case study: Shabestar, Iran. Environmental Earth Sciences, 75(4), 337.

Benjamin, A. M., \& Beasley, J. E. (2010). Metaheuristics for the waste collection vehicle routing problem with time windows, driver rest period and multiple disposal facilities. Computers and Operations Research, 37(12), 2270-2280.

Benjamin, A. M., \& Beasley, J. E. (2013). Metaheuristics with disposal facility positioning for the waste collection VRP with time windows. Optimization Letters, $7(7), 1433-1449$.

Chabuk, A. J., Al-Ansari, N., Hussain, H. M., Knutsson, S., \& Pusch, R. (2017). GIS based assessment of combined AHP and SAW methods for selecting suitable sites for landfill in Al-Musayiab Qadhaa, Babylon, Iraq. Environmental Earth Sciences, 76(5), 209.

Chang, N. B., Parvathinathan, G., \& Breeden, J. B. (2008). Combining GIS with fuzzy multi-criteria decision-making for landfill siting in a fast-growing urban region. Journal of Environmental Management, 87(1), 139-153.

Charnpratheep, K., Zhou, Q., \& Garner, B. (1997). Preliminary landfill site screening using fuzzy geographical information systems. Waste Management \& Research, 15(2), 197-215.

Chaudhary, S., Nidhi, C., \& Rawal, N. R. (2019). GIS-Based Model for Optimal Collection and Transportation System 
for Solid Waste in Allahabad City. In Emerging Technologies in Data Mining and Information Security Springer, Singapore. pp. 45-65.

Cheng, S., Chan, C. W., \& Huang, G. H. (2002). Using multiple criteria decision analysis for supporting decisions of solid waste management. Journal of Environmental Science and Health - Part A Toxicl Hazardous Substances and Environmental Engineering, 37(6), 975-990.

Cheng, S., Chan, C. W., \& Huang, G. H. (2003). An integrated multi-criteria decision analysis and inexact mixed integer linear programming approach for solid waste management. Engineering Applications of Artificial Intelligence, 16(5-6), 543-554.

Delgado-Antequera, L., Laguna, M., Pacheco, J., \& Caballero, R. (2019). A bi-objective solution approach to a real-world waste collection problem. Journal of the Operational Research Society, 1-12.

Ding, Z., Zhu, M., Wang, Y., \& Zhu, J. (2018). An AHP-GIS based model of C\&D waste landfill site selection: A triangulation of critical factors. Proceedings of the 21st International Symposium on Advancement of Construction Management and Real Estate, Singapore: Springer. pp. 163-174,

Gemitzi, A., Tsihrintzis, V. A., Voudrias, E., Petalas, C., \& Stravodimos, G. (2007). Combining geographic information system, multicriteria evaluation techniques and fuzzy logic in siting MSW landfills. Environmental Geology, 51(5), 797-811.

Gorsevski, P. V., Donevska, K. R., Mitrovski, C. D., \& Frizado, J. P. (2012). Integrating multi-criteria evaluation techniques with geographic information systems for landfill site selection: A case study using ordered weighted average. Waste Management, 32(2), 287-296.

Jamshidi-Zanjani, A., \& Rezaei, M. (2017). Landfill site selection using combination of fuzzy logic and multi- attribute decision- making approach. Environmental Earth Sciences, 76, 448.

Jara-Samaniego, J., Pérez-Murcia, M. D., Bustamante, M. A., Pérez-Espinosa, A., Paredes, C., López, M., López-Lluch, D. B., Gavilanes-Terán, I., \& Moral, R. (2017). Composting as sustainable strategy for municipal solid waste management in the Chimborazo Region, Ecuador: Suitability of the obtained composts for seedling production. Journal of Cleaner Production, 141, 1349-1358.

Kahraman, C., Cebi, S., Cevik, S., \& Oztaysi, B. (2018). A novel trapezoidal intuitionistic fuzzy information axiom approach: An application to multi-criteria landfill site selection. Engineering Applications of Artificial Intelligence, 67, 157-172.

Karabulut, K., \& Tasgetiren, M. F. (2014). A variable iterated greedy algorithm for the traveling salesman problem with time windows. Information Sciences, 279: 383395.

Kim, B., Kim, S., \& Sahoo, S. (2006). Waste collection vehicle routing problem with time windows. Computers \& Operations Research, 33, 3624-3642.

Lysgaard, J., Letchford, A. N., \& Eglese, R. W. (2004). A new branch-and-cut algorithm for the capacitated vehicle routing problem. Mathematical Programming, 100(2), 423445 .

Louati, A., \& Chabchoub, H. (2019). Smart routing for municipal solid waste collection: a heuristic approach. Journal of ambient intelligence and humanized computing, 10(5), 1865-1884.

Mat, N. A., Benjamin, A. M., \& Abdul-Rahman, S. (2017). A review on criteria and decisionmaking techniques in solving landfill site selection problems. Journal of Advanced Review on Scientific Research, 37(1), 1432.

Mat, N. A., Benjamin, A. M., \& Abdul-Rahman, S. (2018). Enhanced heuristic algorithms 
with a vehicle travel speed model for time-dependent vehicle routing: A waste collection problem. Journal of Information and Communication Technology, 1(1), 5578 .

Mat, N. A., Benjamin, A. M., Abdul-Rahman, S., \& Wibowo, A. (2016). A framework for landfill site selection using geographic information systems and multi criteria decision making technique. AIP Conference Proceedings 1782, p. 40011.

Mat, N. A., Benjamin, A.M., Abdul-Rahman, S., \& Wibowo, A. (2017). Nearest greedy for solving the waste collection vehicle routing problem: A case study. AIP Conference Proceedings 1905, pp.040018.

Moghaddas, N. H., \& Namaghi, H. H. (2011). Hazardous waste landfill site selection in Khorasan Razavi Province, Northeastern Iran. Arabian Journal of Geosciences, 4(12), 103-113.

Molina, J. C., Eguia, I., \& Racero, J. (2019). Reducing pollutant emissions in a waste collection vehicle routing problem using a variable neighborhood tabu search algorithm: A case study. TOP, 27(2), 253287.

Onut, S., \& Soner, S. (2008). Transshipment site selection using the AHP and TOPSIS approaches under fuzzy environment. Waste Management, 28, 1552-1559.

Rahmat, Z. G., Niri, M. V., Alavi, N., Goudarzi, G., Babaei, A. A., Baboli, Z., \& Hosseinzadeh, M. (2017). Landfill site selection using GIS and AHP: a case study: Behbahan, Iran. KSCE Journal of Civil Engineering, 21(1), 111-118.

Reel, J. S., \& Systems, T. D. (1999). Critical success factors in software projects. IEEE Software, 16(3), 18-23.

Sahoo, S., Kim, S., Kim, B. I., Kraas, B., \& Popov, A. (2005). Routing Optimization for Waste Management. Interfaces, 35(1), 24-36.
Santhosh, L. G., \& Sivakumar Babu, G. L. (2018). Landfill site selection based on reliability concepts using the DRASTIC method and AHP integrated with GIS - a case study of Bengaluru city, India. Georisk: Assessment and Management of Risk for Engineered Systems and Geohazards, 1-19.

Şener, B., Süzen, M. L., \& Doyuran, V. (2006). Landfill site selection by using geographic information systems. Environmental Geology, 49(3), 376-388.

Siddiqui, M. Z., Everett, J. W., \& Vieux, B. E. (1996). Landfill siting using geographic information systems: A demonstration. Journal of Environmental Engineering, 122(6), 515-523.

Somers, T. M., \& Nelson, K. (2001). The impact of critical success factors across the stages of enterprise resource planning implementations. Proceedings of the $34^{\text {th }}$ Hawaii International Conference on System Sciences, pp. 1-10.

Torabi-Kaveh, M., Babazadeh, R., Mohammadi, S. D., \& Zaresefat, M. (2016). Landfill site selection using combination of GIS and fuzzy AHP, a case study: Iran shah, Iran. Waste Management \& Research, 34(5), 438-448.

Vosoogh, A., Baghvand, A., Karbassi, A., \& Nasrabadi, T. (2017). Landfill site selection using pollution potential zoning of aquifers by modified DRASTIC method: Case study in Northeast Iran. Iranian Journal of Science and Technology, Transactions of Civil Engineering, 41(2), 229-239.

Yang G. C. C., Chuang T. N., \& Huang C. W. (2017). Achieving zero waste of municipal incinerator fly ash by melting in electric arc furnaces while steelmaking. Waste Management, 62, 160-168. 